\title{
COLLAGEN QUALITY INDICATORS FOR RADIOCARBON DATING OF BONES: NEW DATA ON BRONZE AGE CYPRUS
}

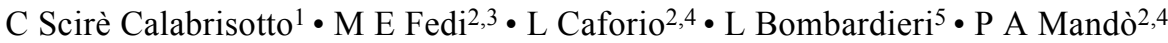

ABSTRACT. Radiocarbon dating of bones can be very useful in archaeological contexts, especially when dealing with funerary deposits lacking material culture, e.g. pottery vessels. ${ }^{14} \mathrm{C}$ measurements of bone samples are usually performed on the extracted collagen residue. The content and the quality of collagen can vary significantly, mainly depending on bone preservation and diagenesis. Generally speaking, environmental conditions such as low $\mathrm{pH}$ level of soils, high temperatures, and percolating groundwaters, typical of arid and tropical zones, can affect the preservation of collagen; at the same time, bones recovered in such environments are more likely to be contaminated with carbon from the surrounding environment. Possible contamination of samples can also occur in temperate zones. While low collagen content is a condition we cannot overcome, we can use several chemical and elemental indicators in order to assess collagen quality. Among these, the $\mathrm{C} / \mathrm{N}$ atomic ratio is considered a good parameter for detecting low-quality collagen and possibly contaminated samples. In a combustion and graphitization setup like that installed at INFN-LABEC, Florence, measurement can be easily performed using an elemental analyzer when combusting the sample prior to graphitization, thus requiring no extra effort (or extra amount of sample) during the preparation procedure. Bone samples recently ${ }^{14} \mathrm{C}$ dated at INFN-LABEC have confirmed that the measurement of $\mathrm{C} / \mathrm{N}$ atomic ratios can give some indications of the collagen quality. The bone material was collected from 3 necropoles of the Bronze Age period in Cyprus (Erimi-Laonin tou Porakou, Lophou-Kolaouzou, and Erimi-Kafkalla\&Pitharka, along the Kouris Valley), an area characterized by environmental conditions that do not favor bone preservation. Samples were treated to extract collagen and measured by accelerator mass spectrometry (AMS). ${ }^{14} \mathrm{C}$ results have been compared with the archaeological evidence, showing some relationship between measured $\mathrm{C} / \mathrm{N}$ atomic ratios and collagen quality. In particular, when grouping the measured samples according to their $\mathrm{C} / \mathrm{N}$ ratio, the agreement between ${ }^{14} \mathrm{C}$ dates and archaeological evidence is good or inconsistent when the $\mathrm{C} / \mathrm{N}$ ratio clearly falls inside or outside the "recommended" range, respectively, with a still reasonable agreement also when it is slightly above the upper limit of that range.

\section{INTRODUCTION}

The interest of archaeologists in radiocarbon dating of bones mainly rests in the possibility of dating a material (bone) that is usually strongly connected to the event to be dated. This is particularly true when dealing with necropoles, especially those consisting of many tombs, with no stratigraphical relation at all, or very poor or undefined grave goods.

Bone is a composite material, characterized by a complex hierarchical structure made up of a mineral phase, essentially hydroxyapatite, including calcium phosphate and calcium carbonate, and an organic matrix predominantly composed of collagen, a fibrous protein that ensures strength and flexibility for the bone (for an overview of bone structure, see Weiner and Traub 1992). Despite various attempts to obtain accurate ${ }^{14} \mathrm{C}$ determinations from the inorganic component of bone (e.g. Haas and Banewics 1980; Saliège et al. 1995), collagen is still the preferable fraction to be collected and ${ }^{14} \mathrm{C}$ dated. However, the content and the quality of collagen can vary significantly, mainly depending on bone preservation and diagenesis (DeNiro and Weiner 1988). In particular, the more deteriorated the collagen, the more relevant is its loss, and the larger the probability for the residual collagen to be contaminated (Hedges and van Klinken 1992). In addition, ${ }^{14} \mathrm{C}$ dating of low-collagen bone samples can be time consuming, with the risk of destroying archaeologically significant material without obtaining any result.

\footnotetext{
${ }^{1}$ Dipartimento di Scienze dell’Antichità, Università di Firenze, Piazza Brunelleschi 4, 50121 Firenze, Italy.

${ }^{2}$ INFN Sezione di Firenze, via Sansone 1, 50019 Sesto Fiorentino (Fi), Italy.

${ }^{3}$ Corresponding author. Email: fedi@fi.infn.it.

${ }^{4}$ Dipartimento di Fisica e Astronomia, via Sansone 1, 50019 Sesto Fiorentino (Fi), Italy.

${ }^{5}$ Dipartimento di Studi Umanistici, Università di Torino, Via Sant'Ottavio 20, 10124 Torino, Italy.
} 


\section{Scirè Calabrisotto et al.}

For these reasons, the preservation state of collagen is of crucial importance when ${ }^{14} \mathrm{C}$ dating bones, and many studies have been performed over the last decades concerning both the mechanisms involved in bone diagenesis (see Collins et al. 2002 for a review) and the environmental parameters affecting the deterioration of collagen (see e.g. Nielsen-Marsh et al. 2007). In fact, it is generally accepted that environmental conditions such as the low $\mathrm{pH}$ level of soils, high temperatures, and percolating groundwaters, typical of arid and tropical zones, can impair conservation of collagen. In light of these considerations, the key issues involved in bone sample preparation for ${ }^{14} \mathrm{C}$ dating concern 2 main questions:

1. Is collagen available in sufficient quantity?

2. Is the residual collagen of good quality, or likely to be contaminated?

As mentioned above, collagen loss is strictly dependent upon bone diagenesis: all the diagenetic processes can in fact deteriorate the organic fraction to the point that not enough organic matter to be ${ }^{14} \mathrm{C}$ dated has remained in the bone sample. Many attempts to define different states of bone preservation through analytical techniques have been made. These include porosity, Fourier transform infrared spectroscopy (FTIR; see Gianfrate et al. 2007), amino acid analysis, protein (percent nitrogen) content, X-ray diffraction, histological studies, and mercury intrusion porosimetry (see Brock et al. 2010 for a review of the most recent prescreening techniques for identification of bone samples suitable for ${ }^{14} \mathrm{C}$ dating).

With respect to the second question above, extensive research has been done in order to assess a range of criteria capable of estimating the quality of the extracted collagen. An overview of bone collagen quality indicators for ${ }^{14} \mathrm{C}$ measurements can be found in van Klinken (1999). Among these, the yield of collagen after extraction and the carbon/nitrogen atomic ratio, measured on the collagen residue, are considered good parameters for detecting low-quality collagen and possibly contaminated samples. In particular, $\mathrm{C} / \mathrm{N}$ measurements can be easily performed using an elemental analyzer when combusting the sample prior to graphitization, thus requiring no extra effort (or extra amount of sample) during the preparation procedure.

In this paper, we discuss bone samples, recently dated at INFN-LABEC in Florence, which have confirmed the importance of measuring collagen quality indicators in order to be confident in the reliability and accuracy of the obtained ${ }^{14} \mathrm{C}$ dates of bones. Samples were collected from 3 necropoles of the Bronze Age period on the southern coast Cyprus, an area characterized by environmental conditions that do not favor bone preservation, in the framework of a project conducted with the Department of Antiquities of Cyprus.

\section{BONE DATING AT INFN-LABEC}

At INFN-LABEC, ${ }^{14} \mathrm{C}$ dating of bone samples is performed on the extracted collagen residue, after demineralization of the sample and cleaning of the extracted material. Bones are first mechanically cleaned with a scalpel and afterward ground in a mortar, then the chemical pretreatment is performed by following a modified procedure derived from the Longin (1971) method:

- Demineralization in $0.5 \mathrm{M} \mathrm{HCl}$ at room temperature for $24 \mathrm{hr}$;

- Purification in $0.1 \mathrm{M} \mathrm{NaOH}$ at room temperature for $2 \mathrm{hr}$;

- Further bath in $1 \mathrm{M} \mathrm{HCl}$ at room temperature for $2 \mathrm{hr}$ to remove any $\mathrm{CO}_{2}$ possibly absorbed from atmosphere during the second step;

- Gelatinization of the collagen-based acidified solution at $80{ }^{\circ} \mathrm{C}$ for $12 \mathrm{hr}$. 


\section{Collagen Quality Indicators for ${ }^{14} \mathrm{C}$ Dating of Bones}

The concentration of the acidic $\mathrm{HCl}$ solution for the first step is usually chosen according to the state of preservation of the bone: if the sample is suspected to have been strongly affected by diagenesis, the concentration is kept as low as possible, for a gentle attack. In this case, when necessary, the duration of this pretreatment step can be maintained for more than $24 \mathrm{hr}$, until complete demineralization is achieved. Moreover, the $\mathrm{HCl}$ solution is frequently changed to improve the efficiency of the reaction.

Only samples whose collagen extraction yield is $1 \mathrm{wt} \%$ (collagen weight with respect to the processed bone) are combusted and converted to graphite using the procedure standard at LABEC (Fedi et al. 2007), and measured by accelerator mass spectrometry (AMS). Combustion is performed by a $\mathrm{CN}$ elemental analyzer, Thermo Flash EA 1112, thus measuring the collagen quality indicator $\mathrm{C} / \mathrm{N}$ ratio at the same time. When possible, $2 \mathrm{C}$ pellets from the same purified sample are prepared. Once verified that the results are consistent, the best estimate of the ${ }^{14} \mathrm{C}$ concentration of each sample is then given by the weighted average of its value in the 2 measured pellets.

All the data presented in this paper were obtained by correcting the measured ${ }^{14} \mathrm{C} /{ }^{12} \mathrm{C}$ isotopic ratios for isotopic fractionation $\left({ }^{13} \mathrm{C} /{ }^{12} \mathrm{C}\right.$ isotopic ratios are also measured in the accelerator) and for background; NIST oxalic Acid II (SRM 4990C) was used as primary standard. Calibration of the measured ${ }^{14} \mathrm{C}$ ages was performed by OxCal v 4 (Bronk Ramsey 2009), using the IntCal09 calibration curve (Reimer et al. 2009). Different ranges of good $\mathrm{C} / \mathrm{N}$ atomic ratios are indicated as recommended in the literature (e.g. DeNiro 1985; van Klinken 1999). We typically consider the interval $2.9-3.6$ as reference.

\section{THE CASE STUDY: BRONZE AGE NECROPOLES IN SOUTH CYPRUS}

The Bronze Age ( $2400-1050 \mathrm{BC})$ is one of the most formative periods in Cypriot prehistory, especially when considering all the cultural and social changes that turned the Cypriot society from a village-based culture, during the second half of the $3 \mathrm{rd}$ millennium $\mathrm{BC}$, into a multicultural, town-centered polity, towards the end of the 2nd millennium BC (Knapp 2008). The periodization of the Bronze Age in Cyprus has been developed over the last decades by a number of different scholars, and it is essentially based on the results of archaeological excavations and pottery classifications, properly synchronized with the Near Eastern and Egyptian chronologies. Nevertheless, it is still under continuous revision. It is important to note that, considering the lack of textual sources that can describe the developments of the Cypriot society, an absolute chronology of Cyprus is necessarily dependent on ${ }^{14} \mathrm{C}$ dates (Manning 2007).

In this paper, we focus the discussion on bone samples collected from 3 Bronze Age necropoles located on the southern coast of Cyprus (see Figure 1): Erimi-Laonin tou Porakou-southern Cemetery Area E (Scirè Calabrisotto et al. 2012); Lophou-Kolaouzou (Violaris et al., forthcoming); and Erimi-Kafkalla\&Pitharka. From an archaeological point of view, the 3 cemeteries show many features in common so that they have been selected as a starting point for mapping and matching necropoles in the south coast region of Cyprus:

- They present a period of utilization spanning since the Early Cypriot until the beginning of the Late Cypriot period ( 2400-1450 BC);

- They pertain to the same territory, namely the Kourion region (Limassol District);

- They are characterized by a peculiar topographic arrangement, with tombs occurring on natural limestone sloping terraces;

- They consist of tombs displaying a similar funerary architecture, mainly corresponding to single rock-cut chambers or pit graves. 


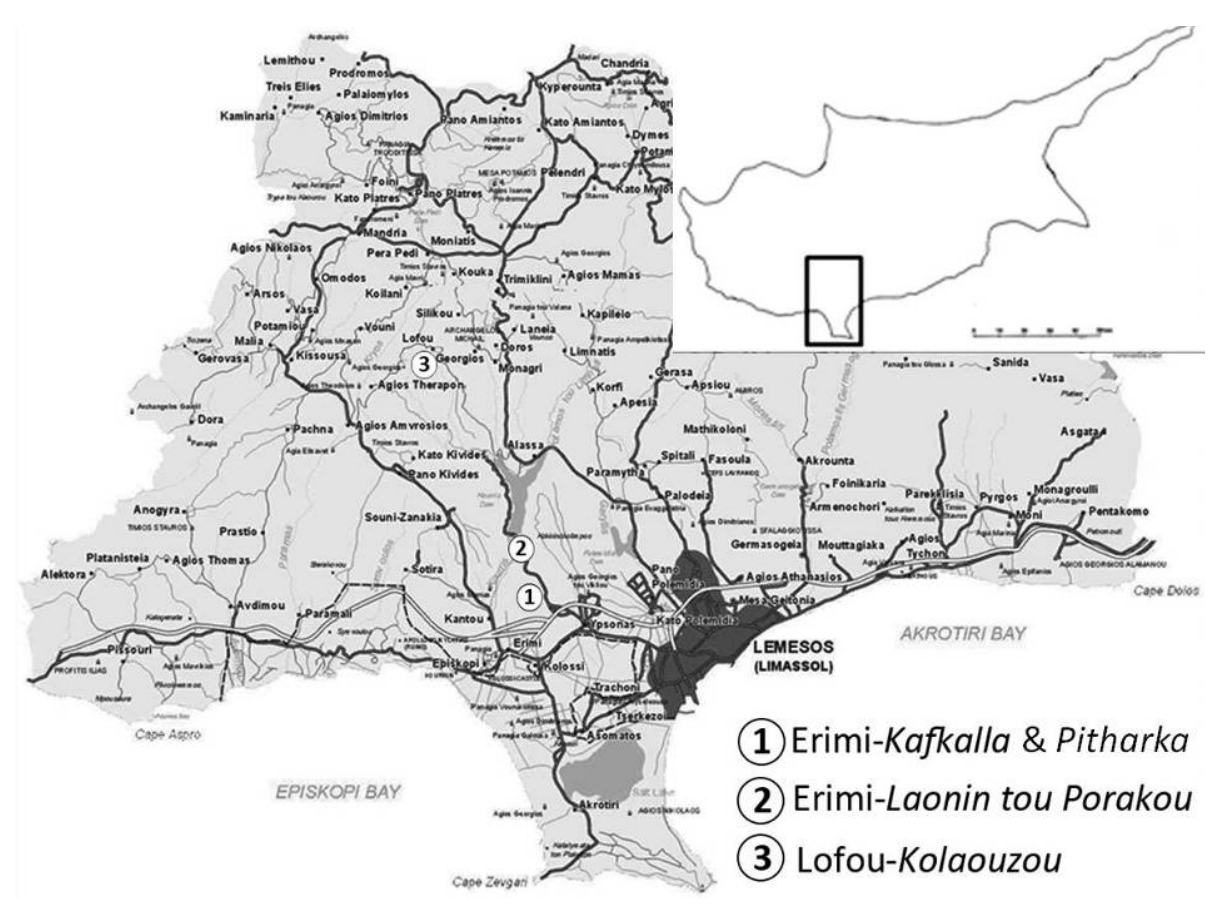

Figure 1 Map of the 3 sites along the Kouris Valley in southern Cyprus studied in this paper

The environmental conditions of the 3 sites do not favor bone preservation. In fact, the 3 areas are characterized by moderate to high calcareous soils contributing to an alkaline environment, and it has been recognized that an alkaline $\mathrm{pH}$ can affect the survival of collagen, causing swelling of the protein and acceleration of hydrolysis. In addition, the soils are rich in groundwaters flowing in highly retentive rocks such as chalk interbedded with marls, and even though not all the mechanisms have been explained yet, the hydrography and moisture of the soil appear to also contribute to bone diagenesis. Finally, collagen deterioration is also caused by high temperatures and Cyprus is indeed characterized by hot temperatures, which can even exceed $40^{\circ} \mathrm{C}$ during summer.

Only long bones, such as femurs or humeri, were chosen for this study, as is typically done in ${ }^{14} \mathrm{C}$ dating (see e.g. Tripp et al. 2010). Unfortunately, as might be expected on the basis of the Cyprus environmental conditions, we actually found that many collected bones were in a very bad state of preservation (not always evident at first sight): about half of the collected samples were not measured since their collagen yield after the pretreatment was insufficient (i.e. $<1 \mathrm{wt} \%$ ). The collagen yield of the measured samples was instead in the range $2-5 \%$.

\section{DISCUSSION OF C/N AND RADIOCARBON RESULTS}

\section{Erimi-Laonin tou Porakou}

The Bronze Age settlement of Erimi-Laonin tou Porakou is located in southern Cyprus, in the Limassol District. The chronology of the site, as inferred from the interpretation of the stratigraphic deposits and analysis of the ceramic assemblage of the 3 areas excavated up to now (Workshop Complex, Domestic Quarter, and Southern Cemetery), points to a period of occupation characterized by 2 main phases, for which 2 possible ranges can be suggested: Early Cypriote III-Middle 


\section{Collagen Quality Indicators for ${ }^{14} \mathrm{C}$ Dating of Bones}

Cypriote I/II (EC III-MC I/II, 2100-1750 BC) for the earlier Phase B, and Middle Cypriote IIILate Cypriote I (MC III-LC I, 1750-1450 BC) for the more recent Phase A (Bombardieri 2011).

As far as ${ }^{14} \mathrm{C}$ dating is concerned, the dated bone samples were collected from 3 tombs, identified as tombs 228,230 and 248, all ascribed to phase A on an archaeological basis $(\sim 1750-1450 \mathrm{BC})$. These were multiple burials from which a single sample per individual (identified after anthropological observations [Bombardieri et al. 2011]) was initially taken for dating. In 1 case (Tomb 230, individual 1), both a femur and a humerus were sampled from the same individual. The results are summarized in Table 1 together with the $\mathrm{C} / \mathrm{N}$ atomic ratios measured during sample combustion, as explained above. For each sample, the first part of the label identifies the tomb where it was found, the second, after the underscore sign, the individual to whom the bone belongs.

Table 1 Results of $\mathrm{C} / \mathrm{N}$ atomic ratios, measured conventional ${ }^{14} \mathrm{C}$ ages, and calibrated ages of bone samples from Erimi-Laonin tou Porakou. Calibrated ages are compared to ages as expected on the basis of the archaeological evidence (Merrillees 1992). Experimental uncertainties on ${ }^{14} \mathrm{C}$ ages are quoted at $1 \sigma$ level. T228_sub, T230_1_o, T230_2 samples were collected from humeri, the other samples from femurs.

\begin{tabular}{|c|c|c|c|c|}
\hline Sample & $\begin{array}{l}\mathrm{C} / \mathrm{N} \\
( \pm 0.2)\end{array}$ & $\begin{array}{l}{ }^{14} \mathrm{C} \text { age } \\
\text { (yr BP) }\end{array}$ & $\begin{array}{l}\text { Calibrated age (BC) } \\
\text { (95\% confidence level) }\end{array}$ & Expected age (BC) \\
\hline T228_1 & 3.4 & $3145 \pm 30$ & $1500-1380$ & $\sim 1750-1450$ \\
\hline T228- sub & 5.7 & n.a. & n.a. & $\sim 1750-1450$ \\
\hline T228 3 & 4.0 & $2140 \pm 50$ & $360 \mathrm{BC}-\mathrm{AD} 45$ & $\sim 1750-1450$ \\
\hline $\mathrm{T} 230^{-} 1 \mathrm{fa}^{\mathrm{a}}$ & 3.4 & $3500 \pm 65$ & $1890-1690$ & $\sim 1750-1450$ \\
\hline T230_1_o & 3.5 & $3450 \pm 55$ & & \\
\hline $\mathrm{T} 230^{-} 2^{-}$ & 3.4 & $3240 \pm 40$ & $1610-1430$ & $\sim 1750-1450$ \\
\hline T248 1 & 3.7 & $3620 \pm 40$ & $2050-1885$ & ح2000/1950-1450 \\
\hline $\mathrm{T} 248^{-} 2$ & 3.8 & $3570 \pm 55$ & $2040-1750$ & 2000/1950-1450 \\
\hline
\end{tabular}

aT230_1 (weighted average).

Before going into the details of the calibrated ages, the measured $\mathrm{C} / \mathrm{N}$ ratios must be discussed. Two samples, T228_sub and T228_3, both from Tomb 228, are characterized by C/N ratios well outside the DeNiro (1985) range (2.9-3.6). After combustion, T228_sub was not measured, since the amount of collected $\mathrm{CO}_{2}$ was too low. On the other hand, T228_3, even though outside the "recommended" $\mathrm{C} / \mathrm{N}$ ratio, was measured, providing a ${ }^{14} \mathrm{C}$ date of the period from the 4 th century $\mathrm{BC}$ to the 1 st century BC, i.e. the Hellenistic Age. However, the offering goods deposits of Tomb 228 do not present any material pertaining to this period: the inconsistency of the measured age, which is much younger with respect to the archaeological evidence, thus reinforces the reliability of the $\mathrm{C} / \mathrm{N}$ ratio criterion as a risk indicator for ${ }^{14} \mathrm{C}$ bone dating.

All the other samples are characterized by $\mathrm{C} / \mathrm{N}$ ratios that either fall within or only slightly outside the DeNiro range, within the experimental uncertainty. Samples from Tomb 228 (T228_1) and from Tomb 230 are indeed roughly consistent with the expected age (compare the Calibrated Age column and the Expected Age column in Table 1). As far as Tomb 248 is concerned, the archaeological evidence suggests that it was used in a very large timespan (embracing both Phase B and Phase A, see the Expected Age column) for multiple burials. The dated samples T248_1 and T248_2, consistent with the earlier Phase B, can support the actual use of the tomb in the older times at least. 


\section{Scirè Calabrisotto et al.}

\section{Lophou-Kolaouzou}

The cemetery of Lophou-Kolaouzou is situated northwest to the Kouris Dam and presently consists of 16 rock-cut tombs, most of which were either interfered with by clandestine digging or by recent bulldozing operations (Violaris et al., forthcoming). The general chronology of the site, as pointed out by the preliminary overall analysis of the funerary architecture types and the material assemblages, suggests a sequence of occupation ranging from the beginning of the Early Cypriot to the end of the Middle Cypriot period (EC I-MC III, 2400-1650 BC).

The results of ${ }^{14} \mathrm{C}$ dating performed on bone samples from tombs 8, 15, 20 (multiple burials), and 21 (single burial) are shown in Table 2. Sample labels are defined as for the case of Erimi-Laonin tou Porakou.

Table 2 Results of $\mathrm{C} / \mathrm{N}$ atomic ratios, measured conventional ${ }^{14} \mathrm{C}$ ages, and calibrated ages of bone samples from Lophou-Kolaouzou. Calibrated ages are compared to ages as expected on the basis of the archaeological evidence (Merrillees 1992). Experimental uncertainties on ${ }^{14} \mathrm{C}$ ages are quoted at the $1 \sigma$ level. All samples were collected from long bones as femurs.

\begin{tabular}{lllll}
\hline Sample & $\begin{array}{l}\mathrm{C} / \mathrm{N} \\
( \pm 0.2)\end{array}$ & $\begin{array}{l}{ }^{14} \mathrm{C} \text { age } \\
(\mathrm{yr} \mathrm{BP})\end{array}$ & $\begin{array}{l}\text { Calibrated age }(\mathrm{BC}) \\
(95 \% \text { confidence level })\end{array}$ & Expected age (BC) \\
\hline LT8_1 & 5.5 & $2580 \pm 60$ & $845-520$ & $\sim 1750-1450$ \\
LT8_2 & 5.9 & $3015 \pm 75$ & $1430-1045$ & $\sim 1750-1450$ \\
LT15_1 & 3.9 & $3685 \pm 40$ & $2150-1950$ & $\sim 2150-1850$ \\
LT15_2 & 3.7 & $3685 \pm 40$ & $2150-1955$ & $\sim 2150-1850$ \\
LT20_2 & 3.8 & $3710 \pm 45$ & $2210-1955$ & $\sim 2150-1850$ \\
LT21 & 4.2 & $3445 \pm 45$ & $1885-1635$ & n.a. \\
\hline
\end{tabular}

As discussed above, samples showing a $\mathrm{C} / \mathrm{N}$ atomic ratio outside the recommended range of 2.9-3.6 can be considered as "problematic" samples, likely to be contaminated. More specifically, the measured values of C/N atomic ratios for samples LT8_1, LT8_2, and LT21 fall well outside the recommend range, thus indicating low-quality collagen samples. Considering the $\mathrm{C} / \mathrm{N}$ ratios, these samples appear unsuitable for ${ }^{14} \mathrm{C}$ dating, and this is indeed confirmed if we compare their measured ages with the expected ages. Actually, LT8_1 and LT8_2, though collected from the same Tomb 8, are not even consistent with each other: they date to the periods 845-520 and 1430-1045 BC, respectively, in disagreement with the expected age that has been estimated on the basis of the analysis of the funerary goods ( 1750-1450 BC). As for sample LT21 (from Tomb 21), unfortunately, a possible dating on the basis of archaeological criteria is not feasible at the moment, because diagnostic materials from this tomb have not been identified yet. We can only comment that the measured ${ }^{14} \mathrm{C}$ age alone cannot be considered a reliable indication, as suggested by the "anomalous" $\mathrm{C} /$ $\mathrm{N}$ ratio.

The other samples LT15_1, LT15_2, collected from Tomb 15, and LT20_2, collected from Tomb 20, are characterized by $\mathrm{C} / \overline{\mathrm{N}}$ atomic ratios that, although not within the recommended $\mathrm{C} / \mathrm{N}$ range, are near its upper limit. They have been ${ }^{14} \mathrm{C}$ dated to a period broadly ranging from the last 2 centuries of the 3rd millennium BC to the 1st century of the 2 nd millennium BC, hence consistent with the chronological range proposed on an archaeological basis (Early Cypriot II/III-Middle Cypriot I, $\sim 2150-1850 \mathrm{BC}$ ). Thus, in these cases, even though the $\mathrm{C} / \mathrm{N}$ ratios may point out to the presence of a small contamination, this is not large enough to affect the ${ }^{14} \mathrm{C}$ data. This result can suggest that the limits of the good $\mathrm{C} / \mathrm{N}$ range should be taken with some critical sensibility, considering the experimental uncertainty on the measured atomic ratios. 
Collagen Quality Indicators for ${ }^{14} \mathrm{C}$ Dating of Bones

\section{Erimi-Kafkalla\&Pitharka}

The wide cemetery area of Erimi-Kafkalla\&Pitharka is located about $3 \mathrm{~km}$ north of the modern village of Erimi, north and south of a present freeway. The Department of Antiquities of Cyprus has excavated over 150 tombs for the last 5 yr. Unfortunately, a large number of the excavated tombs were found looted.

As far as chronology is concerned, exhaustive analyses of the offering good deposits of the 2 necropoles have not been performed yet. At present, it can be argued that the cemetery area of Kafkalla points to a main period of use during the Early Cypriote I to Middle Cypriote III ( 2400-1650 BC), while the necropolis of Pitharka provides evidence for the subsequent Late Cypriote and Iron Age periods ( 1650-850 BC). In addition, Hellenistic and Roman attestations have also been found within the tombs of the 2 necropoles.

The results of ${ }^{14} \mathrm{C}$ dating performed on bone material from Erimi-Kafkalla\&Pitharka are shown in Table 3. Samples KT90_1 and KT90_4, belonging to 2 different individuals, were collected from Tomb 90, located in the necropolis of Pitharka; actually, even though the architecture of this tomb was Bronze Age, only Roman offerings were found during the excavation (Y Violaris, personal communication). Samples KT80_1 and KT78_1 were taken from Tomb 80 and Tomb 78, in the cemetery of Kafkalla. Concerning sample KT $\overline{7} 8$ _ 1 , only the $\mathrm{C} / \mathrm{N}$ atomic ratio is given because the amount of the collected graphite was too small to allow for an AMS measurement.

As seen in Table 3, acceptable $\mathrm{C} / \mathrm{N}$ values were measured for all the dated samples. The calibrated ages are not in agreement with the Bronze Age (compare the Calibrated Ages column and the Expected Ages column in Table 3): samples are dated to the Hellenistic and Roman periods instead. It is worth noting that long-term reuse of Bronze Age funerary areas at Kafkalla and Pitharka is not an isolated occurrence in the region. Actually, evidence of Hellenistic-Roman burials within EBAMBA tombs has been recently documented at Ypsonas-Vounaros, i.e. the eastern tombs cluster of Erimi-Laonin tou Porakou settlement (Christofi et al., forthcoming). Therefore, besides having found grave goods of the Roman period in Tomb 90 , the ${ }^{14} \mathrm{C}$ data themselves suggest the hypothesis of a possible reuse of the older tomb in later periods. In the case of Tomb 80, which is near Tomb 90, assuming the reliability of the ${ }^{14} \mathrm{C}$ dating owing to the measured $\mathrm{C} / \mathrm{N}$ ratio, the date also indicates a later reuse, although this is not corroborated, as for Tomb 90, by relevant goods pointing to any definite period (the burial had been looted in the past).

Table 3 Results of $\mathrm{C} / \mathrm{N}$ atomic ratios, measured conventional ${ }^{14} \mathrm{C}$ ages, and calibrated ages of bone samples from Erimi-Kafkalla and Pitharka. Calibrated ages are compared to ages as expected on the basis of archaeological evidence (Merrillees 1992). Experimental uncertainties on ${ }^{14} \mathrm{C}$ ages are quoted at the $1 \sigma$ level. All samples were collected from long bones as femurs.

\begin{tabular}{lllll}
\hline Sample & $\begin{array}{l}\mathrm{C} / \mathrm{N} \\
( \pm 0.2)\end{array}$ & $\begin{array}{l}{ }^{14} \mathrm{C} \text { age } \\
(\mathrm{yr} \mathrm{BP})\end{array}$ & $\begin{array}{l}\text { Calibrated age } \\
(95 \% \text { confidence level })\end{array}$ & $\begin{array}{l}\text { Expected age } \\
(\mathrm{BC})\end{array}$ \\
\hline KT90_1 & 2.9 & $1650 \pm 60$ & AD 260-540 & $\sim 1650-950$ \\
KT90_4 & 3.2 & $1870 \pm 60$ & AD 0-260 & $\sim 1650-950$ \\
KT80_1 & 3.0 & $2000 \pm 100$ & 220 BC-AD 240 & $\sim 2400-1650$ \\
KT78_1 & 2.6 & n.a. & n.a. & $\sim 2400-1650$ \\
\hline
\end{tabular}

\section{CONCLUSIONS}

${ }^{14} \mathrm{C}$ dating of bones offers archaeologists the opportunity to date an event that is usually strictly associated to the context of the archaeological find. However, different problems can affect the accuracy 


\section{Scirè Calabrisotto et al.}

of ${ }^{14} \mathrm{C}$ dates obtained from bone material. Strong diagenesis processes of the bones, principally due to the duration and the environmental conditions of deposition, might cause a severe loss of the datable organic fraction, mainly collagen, or, at the least, might make the residual collagen more exposed to contamination.

In this article, we have discussed some examples of dated bones collected from archaeological sites in Cyprus whose environmental conditions can be responsible for a strong diagenesis. The dated bones can be divided into 3 different groups. One group (samples T228_sub and T228_3 from Erimi-Laonin tou Porakou; LT8_1, LT8_2, and LT21 from Lophou-Kolaouzou) is characterized by high $\mathrm{C} / \mathrm{N}$ atomic ratios, definitely falling outside the "recommended" range. If we compare their ${ }^{14} \mathrm{C}$ dates with the archaeological evidence, we find a disagreement, suggesting that such high $\mathrm{C} / \mathrm{N}$ ratios indeed indicate a severe contamination. On the contrary, another group (samples T228_1, T230_1_o, T230_1_f, T230_2 from Erimi-Laonin tou Porakou; and KT90_1, KT90_4, KT80_1 from Erimi-Kafkalla\&Pitharka) is characterized by "good" $\mathrm{C} / \mathrm{N}$ ratios. In this case, the measured ${ }^{14} \mathrm{C}$ data are consistent with the archaeological information, at least when the latter is conclusive. Finally, the other samples (T248_1 and T248_2 from Erimi-Laonin tou Porakou; and LT15_1, LT15_2 and LT20_2 from Lophou-Kolaouzou) have C/N ratios that are close to the recommended range, being consistent with the upper limit within the experimental uncertainty. In these cases, the comparison of the measured ${ }^{14} \mathrm{C}$ data with the archaeological evidence suggests that such data can be considered reliable. Of course, we cannot exclude the presence of a contamination altering the $\mathrm{C} /$ $\mathrm{N}$ ratios, which is small enough, however, to not significantly affect the ${ }^{14} \mathrm{C}$ concentration. Even though these data represent a small data set, they seem to indicate that measured $\mathrm{C} / \mathrm{N}$ ratios that are close to the limits of the recommended range should not be a priori rejected but discussed with a critical sensibility. More indications might likely be given by comparing ${ }^{14} \mathrm{C}$ data obtained after different pretreatment methods, as we plan to do in the future.

\section{ACKNOWLEDGMENTS}

We wish to express our gratitude to the Director of the Department of Antiquities of Cyprus, Dr M Hadjikosti, for granting the permission to develop the research project at Erimi, to Mr Y Violaris, for his support and suggestions, and to the kind cooperation of the staff of the District Archaeological Museum of Limassol. We also thank Prof A M Jasink of the University of Florence and the staff of the Italian Embassy in Nicosia for their support. The project is grateful to the Institute of Aegean Prehistory of Philadelphia (INSTAP), the Italian Ministry of Foreign Affairs, the Mediterranean Archaeological Trust, and the Ente CRF for funding and support the 2008-2012 field seasons. The financial support of Regione Toscana (in the framework of the TEMART project - POR CReO/ FESR 2007-2013) is gratefully acknowledged for the position of M E Fedi within INFN.

\section{REFERENCES}

Bombardieri L. 2011. Memory and Change, Sharing and Competition. The Appointment of Spaces and On-Destru within the Bronze Age Cypriot Communities. Padova: Edizioni Munari.

Bombardieri L, Scirè Calabrisotto C, Albertini E, Chelazzi F. 2011. Dating the context (or contextualizing the dating?). New evidence from the Southern Cemetery at Ermi-Laonin tou Porakou, Proceedings of the 11th Annual Meeting of Postgraduate Cypriote Archaeology, Lyon. Cahiers du Centre d'Etudes Cypriotes 41:87-108.

Brock F, Higham T, Bronk Ramsey C. 2010. Pre-screening techniques for identification of samples suitable for radiocarbon dating of poorly preserved bones. Journal of Archaeological Science 37(4):855-65.

Bronk Ramsey C. 2009. Bayesian analysis of radiocarbon dates. Radiocarbon 51(1):337-60.

Christofi P, Stefani E, Bombardieri L. Forthcoming. Bridging the gap: long-term use and re-use of Bronze Age funerary area at Ypsonas-Vounaros and Erimi-Laonin tou Porakou. In: Matthäus H, Vonhoff C, editors. Proceedings of the 12th POCA Meeting. Erlangen, 


\section{Collagen Quality Indicators for ${ }^{14} \mathrm{C}$ Dating of Bones}

23-25 November 2012.

Collins MJ, Nielsen-Marsh CM, Hiller J, Smith CI, Roberts JP, Prigodich RV, Wess TJ, Csapò J, Millard AR, Turner-Walker G. 2002. The survival of organic matter in bone: a review. Archaeometry 44(3):383-94.

DeNiro MJ. 1985. Postmortem preservation and alteration of in vivo bone collagen isotope ratios in relation to palaeodietary reconstruction. Nature 317(6040): 806-9.

DeNiro MJ, Weiner S. 1988. A chemical, enzymatic and spectroscopic characterization of "collagen" and other organic fractions from prehistoric bones. Geochimica et Cosmochimica Acta 52:(9)2197-206.

Fedi ME, Cartocci A, Manetti M, Taccetti F, Mandò PA. 2007. The ${ }^{14} \mathrm{C}$ AMS facility at LABEC, Florence. $\mathrm{Nu}$ clear Instruments and Methods in Physics Research B 259(1):18-22.

Gianfrate G, D'Elia M, Quarta G, Giotta L, Valli L, Calcagnile L. 2007. Qualitative application based on IR spectroscopy for bone sample quality control in radiocarbon dating. Nuclear Instruments and Methods in Physics Research B 259(1):316-9.

Haas H, Banewics JJ. 1980. Radiocarbon dating of bone apatite using Thermal release of $\mathrm{CO}_{2}$. Radiocarbon 22(2):537-44.

Hedges REM, van Klinken J. 1992. A review of current approaches in the pretreatment of bone for radiocarbon dating by AMS. Radiocarbon 34(3):279-91.

Knapp AB. 2008. Prehistoric \& Protohistoric Cyprus. Identity, Insularity and Connectivity. Oxford: Oxford University Press.

Longin R. 1971. New method of collagen extraction for radiocarbon dating. Nature 230(5291):241-2.

Manning SW. 2007. Clarifying the 'High' v. 'Low' Aegean/Cypriot chronology for the mid Second Millennium $\mathrm{BC}$ : assessing the evidence, interpretive frameworks, and current state of the debate. In: Bietak M, Czerny E, editors. The Synchronization of Civilizations in the Eastern Mediterranean in the Second Millennium B.C III. Proceedings of the SCIEM 2000. 2nd EuroConference, Vienna, 28 May-1 June 2003. p 101-37. Vienna: Austrian Academy of Sciences at the Austrian Science Fund.

Merrillees RS. 1992. The absolute chronology of the
Bronze Age in Cyprus: a revision. Bulletin of the American Schools of Oriental Research 288:47-52.

Nielsen-Marsh CM, Smith CI, Jans MME, Nord A, Kars H, Collins MJ. 2007. Bone diagenesis in the European Holocene II: taphonomic and environmental considerations. Journal of Archaeological Science 34(9): 1523-31.

Reimer PJ, Baillie MGL, Bard E, Bayliss A, Beck JW, Blackwell PG, Bronk Ramsey C, Buck CE, Burr GS, Edwards RL, Friedrich M, Grootes PM, Guilderson TP, Hajdas I, Heaton TJ, Hogg AG, Hughen KA, Kaiser KF, Kromer B, McCormac FG, Manning SW, Reimer RW, Richards DA, Southon JR, Talamo S, Turney CSM, van der Plicht J, Weyhenmeyer CE. 2009. IntCa109 and Marine09 radiocarbon age calibration curves, 0-50,000 years cal BP. Radiocarbon 51(4): 1111-50.

Saliège JF, Person A, Paris F. 1995. Preservation of ${ }^{13} \mathrm{C} /$ ${ }^{12} \mathrm{C}$ original ratio and ${ }^{14} \mathrm{C}$ dating of the mineral fraction of human bones from Saharan tombs, Niger. Journal of Archaeological Science 22(2):301-12.

Scirè Calabrisotto C, Fedi ME, Caforio L, Bombardieri L. 2012. Erimi-Laonin tou Porakou (Limassol, Cyprus): radiocarbon analyses in the Bronze Age cemetery and workshop complex. Radiocarbon 54(3-4): 475-82.

Tripp JA, Squire ME, Hamilton J, Hedges REM. 2010. A nondestructive prescreening method for bone collagen content using micro-computed tomography. Radiocarbon 52(2):612-9.

van Klinken GJ. 1999. Bone collagen quality indicators for palaeodietary and radiocarbon measurements. Journal of Archaeological Science 26(6):687-95.

Violaris Y, Bombardieri L, Scirè Calabrisotto C, Fedi ME, Caforio L. Forthcoming. The Bronze Age cemetery at Lofou-Koulauzou (Cyprus): towards a crossanalysis of radiocarbon results and funerary assemblages within the burial contexts. In: Bombardieri L, editor. Identity and Connectivity. Proceedings of the 16th Symposium on Mediterranean Archaeology, Florence, 1-3 March 2012. British Archaeological Reports. Oxford: Archaeopress.

Weiner S, Traub W. 1992. Bone structure: from angstroms to microns. FASEB Journal 6(3):879-85. 